\title{
Saws and the city: smalltooth sawfish Pristis pectinata encounters, recovery potential, and research priorities in urbanized coastal waters off Miami, Florida, USA
}

\author{
Laura H. McDonnell ${ }^{1,2}$, Thomas L. Jackson ${ }^{3}$, George H. Burgess ${ }^{4}$, Lindsay Phenix ${ }^{5,6}$, \\ Austin J. Gallagher ${ }^{5,7}$, Helen Albertson ${ }^{3}$, Neil Hammerschlag ${ }^{1,2}$, Joan A. Browder ${ }^{3, *}$ \\ ${ }^{1}$ Leonard and Jayne Abess Center for Ecosystem Science and Policy, University of Miami, Coral Gables, Florida 33146, USA \\ ${ }^{2}$ Rosenstiel School of Marine and Atmospheric Sciences, University of Miami, Miami, Florida 33149, USA \\ ${ }^{3}$ National Oceanic and Atmospheric Administration, National Marine Fisheries Service, Southeast Fisheries Science Center, \\ Miami, Florida 33149, USA \\ ${ }^{4}$ University of Florida, Gainesville, Florida 32611, USA \\ ${ }^{5}$ Beneath the Waves, Inc., PO Box 126, Herndon, Virginia 20172, USA \\ ${ }^{6}$ Three Seas Program, Northeastern University, 430 Nahant Road Nahant, Massachusetts 01908, USA \\ ${ }^{7}$ Department of Marine Science, Northeastern University, 430 Nahant Road Nahant, Massachusetts 01908, USA
}

\begin{abstract}
As coastal urbanization increases globally, the subsequent effects on marine animals, especially endangered species, inhabiting nearshore waters have become a research priority. The smalltooth sawfish Pristis pectinata, once abundant in US waters, now only persists in a few parts of its former range, including South Florida. Many areas utilized by smalltooth sawfish are estuarine systems or other shallow coastal habitats, making this species particularly vulnerable to threats associated with coastal development. To date, $P$. pectinata has been understudied in the waters in and around Biscayne Bay, Florida, a coastal waterway subjected to the urbanization of adjacent Miami-Dade County. Here, we summarize data from reported smalltooth sawfish encounters dating as far back as $1895(\mathrm{~N}=90)$ and detail opportune recordings (incidental catches, acoustic detections, and baited remote underwater videos) of sub-adults and adults ( $\mathrm{N}=14$ individuals) in Biscayne Bay and the adjacent reef tract. These data demonstrate historical and increased contemporary use of the study area by this imperiled species, suggesting potential local and regional recovery. Most documented sawfish occurrences were near the urban center, indicating a need to understand the effects of coastal urbanization on sawfish and on the species' recovery potential. We suggest priorities for future research on $P$. pectinata in the study area that will assist in addressing regional management goals and contribute to understanding the ecology of smalltooth sawfish under environmental change.
\end{abstract}

KEY WORDS: Conservation - Southeast Florida - Acoustic array - Endangered species · Urban ecology $\cdot$ Biscayne Bay Habitat Focus Area

\section{INTRODUCTION}

Animals living in urban landscapes face different threats and stressors than those inhabiting pristine and relatively intact environments. Threats associated

*Corresponding author: joan.browder@noaa.gov with urbanization include noise, chemical, and light pollution, habitat degradation, and disturbances such as harassment and exploitation. Despite imminent threats from fishing, boat traffic and noise, coastal run-off, and sea-level rise, the effects of urbanization and outside the USA the US Government 2020. Open Access under Creative Commons by Attribution Licence. Use, distribution and reproduction are unrestricted. Authors and original publication must be credited. 
on marine species have not been well studied (Todd et al. 2019). The coastline of Florida (USA) is among the most populous in the world and is regarded as a hotspot for 'coastal syndromes': habitat fragmentation, eutrophication, species loss, and coastal runoff. However, the same waters are inhabited by ecologically and economically important species, including those that are threatened and endangered, such as the smalltooth sawfish Pristis pectinata.

Various regulatory actions have been taken to protect and promote recovery of the US population of $P$. pectinata, which now only persists in a few parts of its former range, including South Florida (NMFS 2009). This species was first provided protection in Florida in 1992 by the Florida Fish and Wildlife Conservation Commission and was further protected by the banning of gillnets in 1994. Due to continued threats to the remaining US population of $P$. pectinata (Seitz \& Poulakis 2006), the species was formally listed as 'endangered' under the US Endangered Species Act (ESA) in 2003. Along with these regulatory actions there has been a pointed effort to protect specific areas to support the conservation and recovery of the remaining US population. The ESA recovery plan for $P$. pectinata identified key research and conservation needs revolving around habitat designation, restoration, and conservation, including identification of historic migration corridors and nursery areas (Carlson et al. 2013).

Many areas utilized by smalltooth sawfish are estuarine systems or other shallow coastal habitats in close proximity to shorelines (Poulakis \& Seitz 2004, Carlson et al. 2014), where they are particularly vulnerable to threats associated with coastal development and urbanization. Nursery areas harboring young of the year and small juveniles have been relatively well studied, and movement patterns within them have been examined (Poulakis et al. 2011, 2013, Norton et al. 2012, Scharer et al. 2017). However, considerably less is known about movements of sub-adult and adult smalltooth sawfish. An enhanced understanding of smalltooth sawfish occurrence, distribution, and habitat use in relation to coastal urbanization is needed to understand the vulnerability of this species to increasing urbanization and related threats (Brame et al. 2019, Poulakis \& Grubbs 2019).

The Biscayne Bay watershed encompasses the city of Miami, one of the largest coastal metropolises in the USA. Located along the southeast Florida coast, Biscayne Bay is a productive estuarine ecosystem; however, the northern part of the bay is a degraded environment. The US National Oceanic and Atmospheric Administration (NOAA) designated Biscayne
Bay and its associated reef tract as a Habitat Focus Area (HFA) in 2015 with the goal of focusing resources and increasing habitat science and conservation efforts in this area. The Biscayne Bay HFA initiative included a stated objective to support and enhance the recovery of smalltooth sawfish (NOAA 2019). However, relatively little is known about the occurrence of this species on Florida's lower east coast. Moreover, $P$. pectinata has previously been considered near-absent from Biscayne Bay (Lewis 2008, Brame et al. 2019). To date, there have been no directed or published studies related to the use of Biscayne Bay and its adjacent reef tract by smalltooth sawfish. Information on the use of the Biscayne Bay HFA by $P$. pectinata is particularly important given that these waters are partially bordered by the Miami metropolitan area and are highly impacted by anthropogenic effects associated with coastal urbanization, including fishing, boating, and pollution (sound, chemical, and light) (Browder et al. 2005).

The lack of scientific coverage of the species in this area has increased the importance of combining local knowledge and data from a public reporting system with recent local scientific efforts to document the presence of endangered species. Citizen-based reported sawfish encounter data have been very useful in providing evidence of habitat use in US waters (Poulakis \& Grubbs 2019), and such data can provide additional support to conservation efforts (Norton et al. 2012). The International Sawfish Encounter Database (ISED) maintains citizen reports from 1782 to present (https://www.floridamuseum.ufl.edu/sawfish/ map/). Reports sent to ISED can include details such as location, method of observation, and estimated capture metrics (if obtained pre-release) and consist of encounters by both the public (boaters, recreational fishers, etc.) and researchers.

The present study summarizes patterns of encounters of this species from ISED reports and an independent historical search and provides details on recent opportunistic recordings from a suite of research methods on both sub-adult and adult smalltooth sawfish within the Biscayne Bay HFA. We recommend research priorities for $P$. pectinata in this urbanized coastal waterway based on our findings.

\section{MATERIALS AND METHODS}

\subsection{Study area}

The study region is subject to a humid sub-tropical climate, characterized by a hot and rainy 'wet sea- 
son' (May-October) and a relatively colder and more arid 'dry season' (November-April). During the wet season, coastal waters exhibit relatively higher temperatures and lower salinities, whereas during the dry season, they exhibit relatively lower temperatures and higher salinities.
The Biscayne Bay HFA, as designated by NOAA in 2015, extends nearly $80 \mathrm{~km}$ from northern Dumfoundling Bay to southern Barnes Sound and Manatee Bay, encompassing the entirety of Biscayne Bay and its connected reef tracts (Fig. 1). Biscayne Bay is a shallow, clearwater lagoon with a predominantly

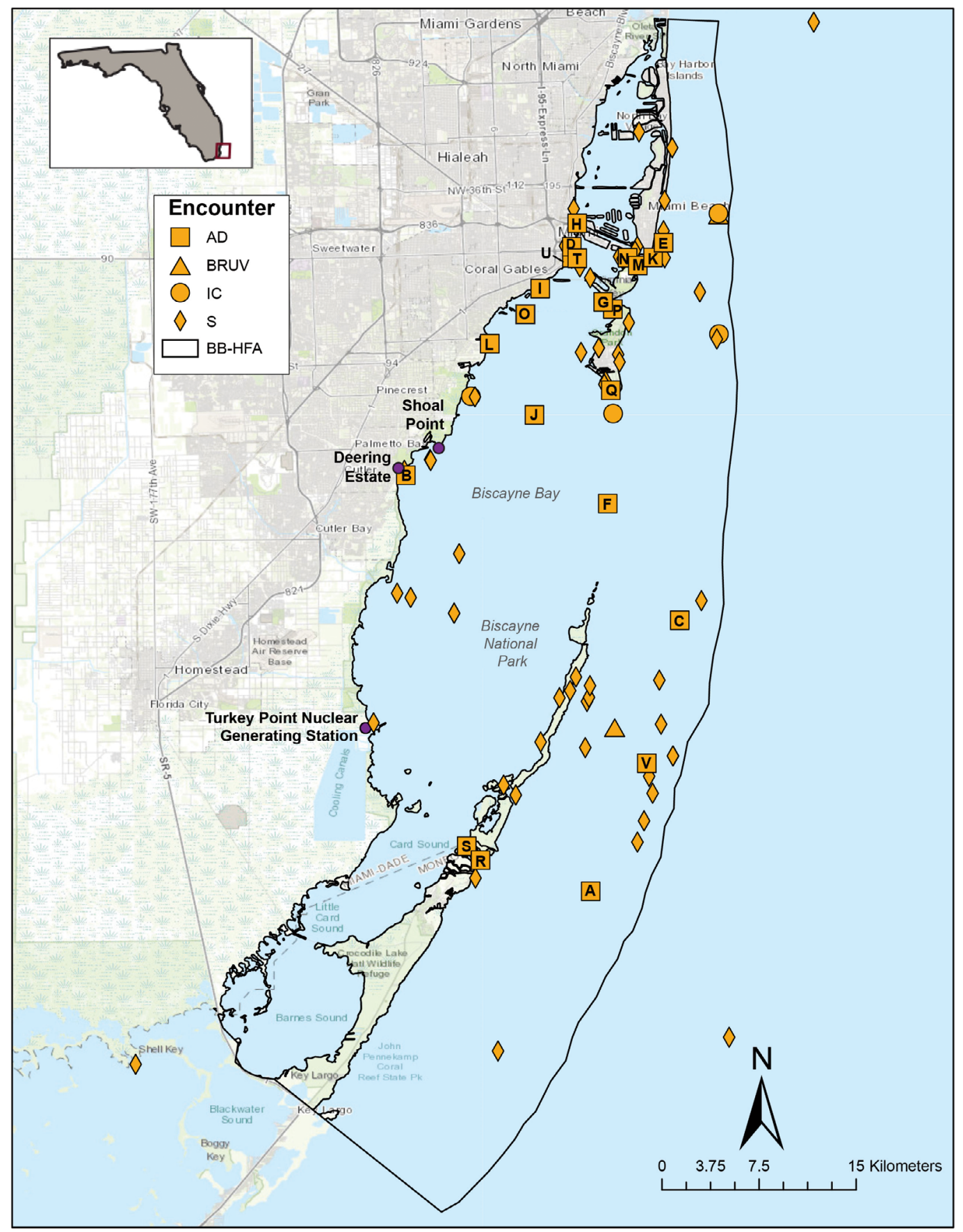

Fig. 1. All smalltooth sawfish encounter locations $(\mathrm{N}=112)$. These 112 locations include 90 from historical and recent sightings (S), baited underwater remote videos (BRUVs), and incidental catches (IC) in addition to 22 receiver locations with acoustic detections (AD), labeled with letters (as in Fig. 4). Locations of Turkey Point nuclear plant, Shoal Point, and Deering Estate are also shown (purple dots) 
benthic-based ecosystem (Browder et al. 2005) that supports a wide array of marine species, including seagrasses and hard and soft corals. The northern half of the Biscayne Bay HFA borders the Miami metropolitan area; therefore, its waters are affected by urbanization and anthropogenic activities, including boating and recreational fishing (Browder et al. 2005). A natural coastline with a mangrove fringe and slight shoreline indentations borders Biscayne Bay.

Since it was hydrologically connected to the Everglades, Biscayne Bay has had its watershed drastically altered over the past century for both agricultural and urban purposes, changing the quantity and timing of freshwater flow to the bay and replacing natural flow paths with canals (Browder et al. 2005). This has increased salinity, converting the bay from estuarine conditions to more oceanic conditions. However, new water management policies encapsulated in the Comprehensive Everglades Restoration Plan (CERP) have sought to restore historical flow patterns to Biscayne Bay to convert it to a more natural estuarine system (USACE 2019). Water pumping stations to distribute canal flows into sheet flows have already been established at certain locations in the southcentral bay, redistributing freshwater input along the shoreline in a phased approach (NOAA $2019,2020)$. These restoration efforts are relevant to the smalltooth sawfish, whose juveniles prefer estuarine conditions (Simpfendorfer et al. 2011).

\subsection{Data collection}

Several independent data sources were used to compile historic and current records of smalltooth sawfish within the Biscayne Bay HFA. These were: (1) literature searches, including public news sources, (2) encounter records reported to the ISED, and (3) recent opportune encounters with smalltooth sawfish by our research team during unrelated research surveys. Details on each approach are described below.

A literature search was completed in 2020 with the aim of finding historical records of smalltooth sawfish within the area that became designated the Biscayne Bay HFA, as well as compiling more recent sightings reported to public news outlets. This search was conducted using standard electronic resources, i.e. Web of Science (ISI) and Aquatic Sciences and Fisheries Abstracts (ASFA; ProQuest) with 'Sawfish in Biscayne Bay' and 'Sawfish in Miami' as qualifiers. In addition, local news sources and their archives, including the Palm Beach Post (1904-present) and
Miami Herald (1911-present), were searched using the same qualifiers.

Smalltooth sawfish records in Miami-Dade were also collected from ISED with data download requests in 2019 and 2020. All records obtained from ISED and the bibliographic search were compiled and compared. Any duplicate observations (reports of the same sawfish at the same location and time but from different people) were combined. While we summarize and report all records from these sources, only those with adequate time (month/year) and location data (GPS coordinates provided by the reporter or assigned by ISED) were included in spatial analyses.

Between 2017 and 2020, our research team incidentally encountered smalltooth sawfish during several different research surveys in the Biscayne Bay HFA to monitor the habitat use and relative abundance of coastal sharks and fish. These included (1) incidental catches of smalltooth sawfish on drumlines, (2) recordings on baited-remote underwater video (BRUV) stations, and (3) detections of acoustically tagged sawfish on underwater receivers (hydrophones). Since 2009, we have been conducting standardized circle-hook drumline shark surveys (described by Gallagher et al. 2014) to monitor shark spatiotemporal patterns in the area. Between 2017 and 2018, we deployed BRUVs within Biscayne Bay to compare the abundance, richness, and behavior of fish species in different habitats and management regions (Fig. S1 in the Supplement at www.int-res. com/articles/suppl/n043p543_supp.pdf; BRUV set-up and procedures described by Phenix et al. 2019 and Enchelmaier et al. 2020). To record the presence of sharks, we have acoustically tagged sawfish with $69 \mathrm{kHz}$ Vemco transmitters, and we maintain an array of 40 single-frequency omnidirectional VR2W Vemco acoustic receivers (installed in stages beginning in 2016), positioned mainly in the urban environment of the bay, but also in other parts of the Biscayne Bay HFA (Figs. 1 \& S2), These hydrophones can detect the presence of any acoustically tagged animal carrying a compatible $69 \mathrm{kHz}$ Vemco transmitter that enters their detection range $(\sim 500-1000 \mathrm{~m}$; see description in Hammerschlag et al. 2017).

Based on information available from all smalltooth sawfish records, we extracted the date and location of the encounter as well as the identity code and size and sex of the sawfish, if available. Total length (TL: length from rostrum to caudal fin) of sawfish caught on drumlines was estimated using the boatbased $3.6 \mathrm{~m}$ wide platform as a reference during release. For individuals detected on BRUVs, TLs 
were estimated relative to the dimensions of the attached bait crate $(17.8 \times 12.7 \times 8.9 \mathrm{~cm}[7 \times 5 \times$ 3.5 inches]; length $\times$ width $\times$ height), as approached by the sawfish. The TL of all acoustically detected individuals was measured on the tagging date. Information from all mentioned sources was screened for temporal, spatial, or seasonal patterns in the occurrence of smalltooth sawfish in the Biscayne Bay HFA. Encounters with associated GPS data (latitude and longitude) were mapped using ArcGIS Pro software (ESRI), and spatial spread was examined.

\section{RESULTS}

\subsection{Records, literature, and news source search}

A total of 90 historical and recent smalltooth sawfish encounter records in Miami-Dade County were obtained from a combination of the literature search, news reports, and available ISED reports (Fig. 2, Table S1). We found that sawfish sightings in the study area date back to at least 1895. The search of literature, archives, and other sources yielded several accounts from 1905 to $1929(\mathrm{~N}=18)$, including 1 reference to a location called 'the sawfish hole' that was posted in the Miami Daily Metropolis on 20 May 1909. Among the total 90 records collected from our searches, we noted that 8 sightings from the Biscayne Bay HFA with sufficient details required for inclusion in ISED were not yet posted in the database; we have since submitted our records of these to ISED. Of these, 4 were from historical archives while the other 4 were very recent sightings (2019, 2020) detailed in public news sources. The search for records from this area also resulted in several images of sawfish captured in Miami-Dade waters, photographed during the early decades of the $20^{\text {th }}$ century (Fig. 3A).

Of all 90 reported encounters, $51 \%$ $(\mathrm{N}=46)$ occurred within the last decade (Figs. 1 \& 3B). Over three-quarters (77\%, N = 69) of all encounters had precise location data assigned to them and, of these, $96 \%(\mathrm{~N}=66)$ were within the Biscayne Bay HFA (Fig. 1). Over half $(\mathrm{N}=49)$ of the encounter records included estimated TL, which ranged from 122 to $549 \mathrm{~cm}$ (mean = $294.75 \mathrm{~cm}$ ). Sixteen of estimated TLs were within the juvenile size range, i.e. $<220 \mathrm{~cm}$ (Brame et al. 2019). Season of encounter was determined for records with sufficient date information (69 records): 48 were encountered during the wet season and 21 during the dry season.

Fig. 2. (A) All historical and recent sightings (cumulative, $N=90$ ) of smalltooth sawfish in Miami-Dade County from 1890 to 2020 from the International Sawfish Encounter Database and historical literature data sources. (B) More recent encounters are enlarged to provide more resolution and to highlight important dates. Vertical green lines mark the date of listing of smalltooth sawfish on the US Endangered Species List (April 2003, ESA), implementation of the Biscayne Bay Coastal Wetlands (BBCW) Project of the Comprehensive Everglades Restoration Plan (CERP) at Deering Estate (Fig. 1) (December 2012, CERP 1), and incrementation of pumping from $12 \mathrm{~h}$ on $12 \mathrm{~h}$ off flows to continuous flows (September 2018, CERP 2)

\subsection{Recent incidental encounters}

We deployed 12215 drumlines in the area of the Biscayne Bay HFA over $10 \mathrm{yr}$ (2009-2018), catching and releasing 

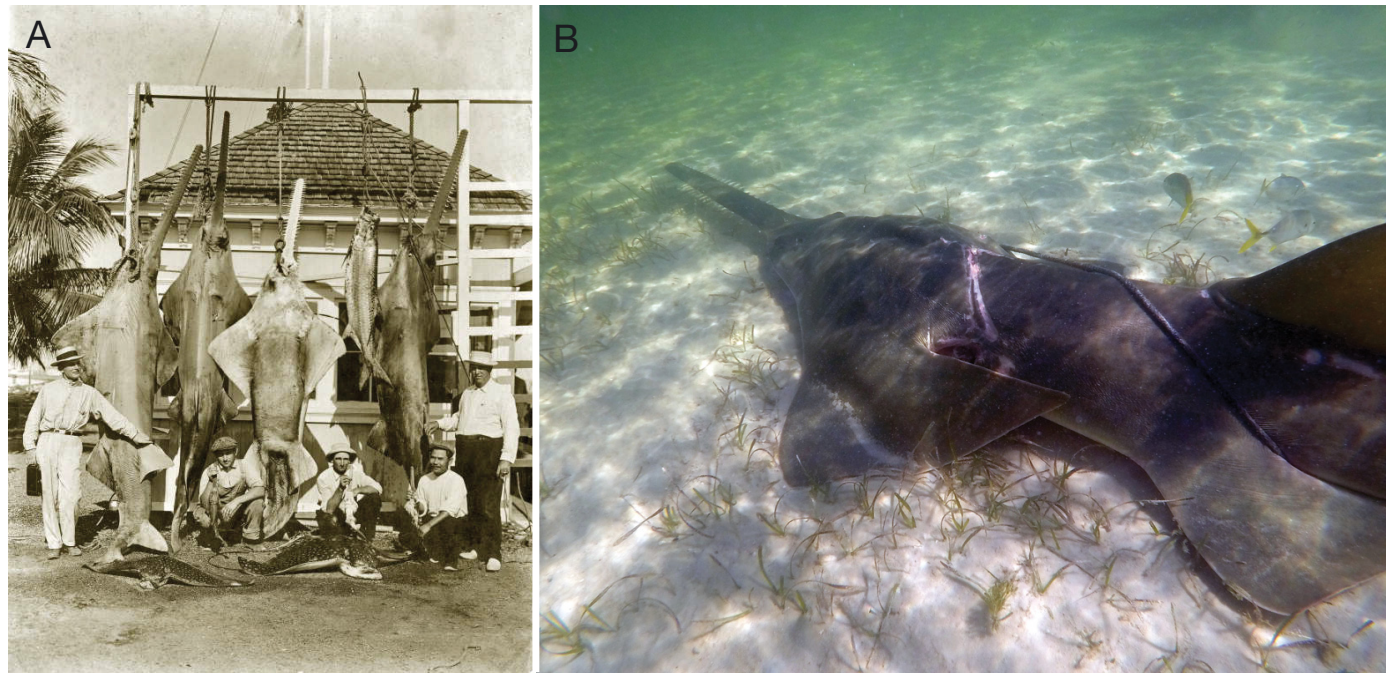

Fig. 3. (A) Photograph taken by W. A. Fishbaugh in the 1920s, recorded as taken in Miami (courtesy of State Library \& Archives of Florida, Florida: https://www.floridamemory.com/items/show/165364). (B) Photograph taken by 2 national park rangers in Biscayne Bay National Park near Elliott Key on 23 November 2018, showing a smalltooth sawfish entangled in fishing gear (courtesy of Biscayne National Park: https://www.fisheries.noaa.gov/feature-story/saving-endangered-sawfish)

1808 sharks. We deployed 221 BRUV stations throughout the Biscayne Bay HFA between 2016 and 2018 (Table 1, Fig. S1). We established an array of 40 acoustic recorders in the Biscayne Bay HFA between 2015 and 2017, and the maintenance and collection of data from these is ongoing (Table 1, Fig. S2). Acoustic data collected from January 2017 to April 2020 are reported here.

Three activities targeting sharks in the area of the Biscayne Bay HFA within the past 4 yr (2017-2020) incidentally encountered 14 individual smalltooth sawfish: drumlines incidentally captured 4 individuals in 2018, all were released immediately in good condition (Fig. 1); BRUVs recorded 2 individuals in 2017 and 2018; and 8 individuals were detected on the acoustic array between 2017 and 2020 (Table 1). The smalltooth sawfish incidentally encountered on drumlines and on BRUVs were immediately reported to ISED and are therefore included in the 90 records described in the previous section (Table S1). The size differences of the drumline captures and those observed on the BRUVs indicate that they were not the same individuals, and the lack of any external tags indicates that none of these were the same individuals detected on the acoustic arrays. Their relatively small size indicated that the 2 smalltooth sawfish on BRUVcamera captures were sub-adults.

Acoustic records of smalltooth sawfish in the Biscayne Bay HFA are worth noting further. The 8 smalltooth sawfish individuals were detected on 22 different acoustic receivers within the Biscayne Bay HFA between 2017 and 2020, for a total of 487 indi- vidual detections (Figs. 1 \& S2). All individuals were tagged by authorized investigators who were not part of this study (Table 1). Six of the detected sawfish had been tagged in the Florida Keys and were detected 447 times in the Biscayne Bay HFA (Table 1). In addition, 2 individuals originally tagged in Port St. Lucie were detected 40 times in the Biscayne Bay HFA (Table 1). Individuals remaining within the array for prolonged periods often moved between receivers (Table 1, Fig. 4). Six of the 8 individuals were detected on more than 1 receiver within the array, while 5 individuals were detected in more than 1 year (Table 1 , Fig. 4). Wet seasons accounted for $58 \%$ of detections. Approximately $49 \%$ of detections were logged on 1 receiver located off South Beach (Fig. 1, receiver E), with 7 out of 8 individuals detected at this location, while $25 \%$ of total detections occurred near Fisher Island (Fig. 1, receivers $\mathrm{M}$ and $\mathrm{N}$ ).

\section{DISCUSSION}

While the use of Biscayne Bay and surrounding waters by smalltooth sawfish has previously been unstudied, our investigation uncovered 90 individual smalltooth sawfish encounters (not counting repeated encounters with the same individuals from the acoustic array) in the Biscayne Bay HFA, with sightings dating as far back as 1895 . These data suggest both historical and contemporary use of the area by this imperiled species. Occurrences were mainly in waters bordered by highly urbanized areas near 
Table 1. Recent smalltooth sawfish Pristis pectinata encounters in the Biscayne Bay Habitat Focus Area, recorded from incidental captures (IC), baited remote underwater video (BRUV) sightings, and acoustic detections (AD) of tagged individuals in chronological order of first recording. TL: total length. Tagging details are included for the first detection; subsequent detection details of the same individual are provided. Data sources are SRC: University of Miami Shark Research \& Conservation Program; BTW: Beneath the Waves; FWC: Florida Fish and Wildlife Conservation Commission (ESA Permit No. 21043); NOAA: National Oceanic and Atmospheric Association (ESA Permit No. 17787-01). Dates are given as mo/d/yr; NA: not applicable; ND: not determined

\begin{tabular}{|c|c|c|c|c|c|c|c|}
\hline ID & Date & Geographic coordinates & Discrete detections (AD) & Data source & Sex & Life stage & Estimated TL (cm) \\
\hline \multirow[t]{33}{*}{1} & 01/13/2017 & $25^{\circ} 45^{\prime} 23^{\prime \prime} \mathrm{N}, 80^{\circ} 8^{\prime} 32^{\prime \prime} \mathrm{W}$ & 1 & \multirow[t]{33}{*}{$\mathrm{AD}$ (NOAA) } & \multirow[t]{33}{*}{$\mathrm{F}$} & \multirow[t]{33}{*}{ Adult } & \multirow[t]{33}{*}{438} \\
\hline & 05/17/2017 & $25^{\circ} 40^{\prime} 11^{\prime \prime} \mathrm{N}, 80^{\circ} 9^{\prime} 40^{\prime \prime} \mathrm{W}$ & 4 & & & & \\
\hline & $05 / 18 / 2017$ & $25^{\circ} 45^{\prime} 43^{\prime \prime} \mathrm{N}, 80^{\circ} 11^{\prime} 27^{\prime \prime} \mathrm{W}$ & 1 & & & & \\
\hline & 09/21/2017 & $25^{\circ} 46^{\prime} 20^{\prime \prime} \mathrm{N}, 80^{\circ} 7^{\prime} 28^{\prime \prime} \mathrm{W}$ & 50 & & & & \\
\hline & 09/24/2017 & $25^{\circ} 45^{\prime} 23^{\prime \prime} \mathrm{N}, 80^{\circ} 8^{\prime} 32^{\prime \prime} \mathrm{W}$ & 69 & & & & \\
\hline & $09 / 24 / 2017$ & $25^{\circ} 46^{\prime} 20^{\prime \prime} \mathrm{N}, 80^{\circ} 7^{\prime} 28^{\prime \prime} \mathrm{W}$ & 20 & & & & \\
\hline & $09 / 25 / 2017$ & $25^{\circ} 45^{\prime} 43^{\prime \prime} \mathrm{N}, 80^{\circ} 8^{\prime} 58^{\prime \prime} \mathrm{W}$ & 4 & & & & \\
\hline & 09/26/2017 & $25^{\circ} 40^{\prime} 11^{\prime \prime} \mathrm{N}, 80^{\circ} 9^{\prime} 40^{\prime \prime} \mathrm{W}$ & 2 & & & & \\
\hline & 09/26/2017 & $25^{\circ} 46^{\prime} 20^{\prime \prime} \mathrm{N}, 80^{\circ} 7^{\prime} 28^{\prime \prime} \mathrm{W}$ & 50 & & & & \\
\hline & 09/30/2017 & $25^{\circ} 46^{\prime} 20^{\prime \prime} \mathrm{N}, 80^{\circ} 7^{\prime} 28^{\prime \prime} \mathrm{W}$ & 29 & & & & \\
\hline & $10 / 24 / 2017$ & $25^{\circ} 40^{\prime} 11^{\prime \prime} \mathrm{N}, 80^{\circ} 9^{\prime} 40^{\prime \prime} \mathrm{W}$ & 2 & & & & \\
\hline & 09/05/2019 & $25^{\circ} 45^{\prime} 43^{\prime \prime} \mathrm{N}, 80^{\circ} 7^{\prime} 54^{\prime \prime} \mathrm{W}$ & 1 & & & & \\
\hline & $09 / 06 / 2019$ & $25^{\circ} 45^{\prime} 23^{\prime \prime} \mathrm{N}, 80^{\circ} 8^{\prime} 32^{\prime \prime} \mathrm{W}$ & 3 & & & & \\
\hline & 09/06/2019 & $25^{\circ} 45^{\prime} 43^{\prime \prime} \mathrm{N}, 80^{\circ} 8^{\prime} 58^{\prime \prime} \mathrm{W}$ & 2 & & & & \\
\hline & 09/09/2019 & $25^{\circ} 19^{\prime} 19^{\prime \prime} \mathrm{N}, 80^{\circ} 10^{\prime} 30^{\prime \prime} \mathrm{W}$ & 2 & & & & \\
\hline & $03 / 11 / 2020$ & $25^{\circ} 43^{\prime} 52^{\prime \prime} \mathrm{N}, 80^{\circ} 9^{\prime} 52^{\prime \prime} \mathrm{W}$ & 1 & & & & \\
\hline & $03 / 12 / 2020$ & $25^{\circ} 21^{\prime} 12^{\prime \prime} \mathrm{N}, 80^{\circ} 15^{\prime} 40^{\prime \prime} \mathrm{W}$ & 9 & & & & \\
\hline & $03 / 13 / 2020$ & $25^{\circ} 45^{\prime} 43^{\prime \prime} \mathrm{N}, 80^{\circ} 7^{\prime} 54^{\prime \prime} \mathrm{W}$ & 6 & & & & \\
\hline & 03/14/2020 & $25^{\circ} 45^{\prime} 43^{\prime \prime} \mathrm{N}, 80^{\circ} 8^{\prime} 58^{\prime \prime} \mathrm{W}$ & 16 & & & & \\
\hline & 03/18/2020 & $25^{\circ} 45^{\prime} 43^{\prime \prime} \mathrm{N}, 80^{\circ} 11^{\prime} 27^{\prime \prime} \mathrm{W}$ & 1 & & & & \\
\hline & $03 / 20 / 2020$ & $25^{\circ} 46^{\prime} 10^{\prime \prime} \mathrm{N}, 80^{\circ} 11^{\prime} 17^{\prime \prime} \mathrm{W}$ & 1 & & & & \\
\hline & $03 / 21 / 2020$ & $25^{\circ} 45^{\prime} 42^{\prime \prime} \mathrm{N}, 80^{\circ} 11^{\prime} 3^{\prime \prime} \mathrm{W}$ & 6 & & & & \\
\hline & $03 / 21 / 2020$ & $25^{\circ} 45^{\prime} 43^{\prime \prime} \mathrm{N}, 80^{\circ} 11^{\prime} 27^{\prime \prime} \mathrm{W}$ & 3 & & & & \\
\hline & $03 / 21 / 2020$ & $25^{\circ} 44^{\prime} 26^{\prime \prime} \mathrm{N}, 80^{\circ} 12^{\prime} 36^{\prime \prime} \mathrm{W}$ & 7 & & & & \\
\hline & $03 / 21 / 2020$ & $25^{\circ} 43^{\prime} 22^{\prime \prime} \mathrm{N}, 80^{\circ} 13^{\prime} 13^{\prime \prime} \mathrm{W}$ & 3 & & & & \\
\hline & $03 / 21 / 2020$ & $25^{\circ} 42^{\prime} 8^{\prime \prime} \mathrm{N}, 80^{\circ} 14^{\prime} 42^{\prime \prime} \mathrm{W}$ & 2 & & & & \\
\hline & $03 / 22 / 2020$ & $25^{\circ} 43^{\prime} 52^{\prime \prime} \mathrm{N}, 80^{\circ} 9^{\prime} 52^{\prime \prime} \mathrm{W}$ & 2 & & & & \\
\hline & 03/23/2020 & $25^{\circ} 45^{\prime} 43^{\prime \prime} \mathrm{N}, 80^{\circ} 7^{\prime} 54^{\prime \prime} \mathrm{W}$ & 1 & & & & \\
\hline & $04 / 03 / 2020$ & $25^{\circ} 47^{\prime} 9^{\prime \prime} \mathrm{N}, 80^{\circ} 11^{\prime} 3^{\prime \prime} \mathrm{W}$ & 4 & & & & \\
\hline & $04 / 03 / 2020$ & $25^{\circ} 46^{\prime} 10^{\prime \prime} \mathrm{N}, 80^{\circ} 11^{\prime} 17^{\prime \prime} \mathrm{W}$ & 2 & & & & \\
\hline & $04 / 03 / 2020$ & $25^{\circ} 45^{\prime} 42^{\prime \prime} \mathrm{N}, 80^{\circ} 11^{\prime} 3^{\prime \prime} \mathrm{W}$ & 2 & & & & \\
\hline & $04 / 03 / 2020$ & $25^{\circ} 45^{\prime} 43^{\prime \prime} \mathrm{N}, 80^{\circ} 11^{\prime} 27^{\prime \prime} \mathrm{W}$ & 6 & & & & \\
\hline & $04 / 04 / 2020$ & $25^{\circ} 21^{\prime} 12^{\prime \prime} \mathrm{N}, 80^{\circ} 15^{\prime} 40^{\prime \prime} \mathrm{W}$ & 1 & & & & \\
\hline \multirow[t]{2}{*}{2} & $04 / 20 / 2017$ & $25^{\circ} 20^{\prime} 37^{\prime \prime} \mathrm{N}, 80^{\circ} 15^{\prime} 5^{\prime \prime} \mathrm{W}$ & 2 & \multirow[t]{2}{*}{$\mathrm{AD}(\mathrm{NOAA})$} & \multirow[t]{2}{*}{$\mathrm{F}$} & \multirow[t]{2}{*}{ Sub-adult } & \multirow[t]{2}{*}{355} \\
\hline & $04 / 24 / 2017$ & $25^{\circ} 21^{\prime} 12^{\prime \prime} \mathrm{N}, 80^{\circ} 15^{\prime} 40^{\prime \prime} \mathrm{W}$ & 18 & & & & \\
\hline 3 & $7 / 28 / 2017$ & $25^{\circ} 26^{\prime} 11^{\prime \prime} \mathrm{N}, 80^{\circ} 9^{\prime} 30^{\prime \prime} \mathrm{W}$ & NA & BRUV (BTW) & ND & Sub-adult & 300 \\
\hline 4 & $9 / 28 / 2017$ & $25^{\circ} 46^{\prime} 20^{\prime \prime} \mathrm{N}, 80^{\circ} 7^{\prime} 28^{\prime \prime} \mathrm{W}$ & 29 & $\mathrm{AD}(\mathrm{FWC})$ & M & Adult & 349.5 \\
\hline \multirow[t]{19}{*}{5} & 03/08/2018 & $25^{\circ} 45^{\prime} 23^{\prime \prime} \mathrm{N}, 80^{\circ} 8^{\prime} 32^{\prime \prime} \mathrm{W}$ & 3 & \multirow[t]{19}{*}{$\mathrm{AD}$ (NOAA) } & \multirow[t]{19}{*}{$\mathrm{F}$} & \multirow[t]{19}{*}{ Adult } & \multirow[t]{19}{*}{426} \\
\hline & 03/08/2018 & $25^{\circ} 45^{\prime} 43^{\prime \prime} \mathrm{N}, 80^{\circ} 8^{\prime} 58^{\prime \prime} \mathrm{W}$ & 1 & & & & \\
\hline & 03/08/2018 & $25^{\circ} 45^{\prime} 43^{\prime \prime} \mathrm{N}, 80^{\circ} 7^{\prime} 54^{\prime \prime} \mathrm{W}$ & 1 & & & & \\
\hline & 03/09/2018 & $25^{\circ} 46^{\prime} 20^{\prime \prime} \mathrm{N}, 80^{\circ} 7^{\prime} 28^{\prime \prime} \mathrm{W}$ & 29 & & & & \\
\hline & 03/12/2018 & $25^{\circ} 45^{\prime} 23^{\prime \prime} \mathrm{N}, 80^{\circ} 8^{\prime} 32^{\prime \prime} \mathrm{W}$ & 11 & & & & \\
\hline & $03 / 12 / 2018$ & $25^{\circ} 45^{\prime} 43^{\prime \prime} \mathrm{N}, 80^{\circ} 7^{\prime} 54^{\prime \prime} \mathrm{W}$ & 1 & & & & \\
\hline & $03 / 14 / 2018$ & $25^{\circ} 43^{\prime} 35^{\prime \prime} \mathrm{N}, 80^{\circ} 9^{\prime} 35^{\prime \prime} \mathrm{W}$ & 1 & & & & \\
\hline & 03/20/2018 & $25^{\circ} 40^{\prime} 11^{\prime \prime} \mathrm{N}, 80^{\circ} 9^{\prime} 40^{\prime \prime} \mathrm{W}$ & 9 & & & & \\
\hline & $03 / 24 / 2018$ & $25^{\circ} 43^{\prime} 35^{\prime \prime} \mathrm{N}, 80^{\circ} 9^{\prime} 35^{\prime \prime} \mathrm{W}$ & 6 & & & & \\
\hline & $04 / 03 / 2018$ & $25^{\circ} 40^{\prime} 11^{\prime \prime} \mathrm{N}, 80^{\circ} 9^{\prime} 40^{\prime \prime} \mathrm{W}$ & 5 & & & & \\
\hline & $03 / 01 / 2020$ & $25^{\circ} 40^{\prime} 11^{\prime \prime} \mathrm{N}, 80^{\circ} 9^{\prime} 40^{\prime \prime} \mathrm{W}$ & 1 & & & & \\
\hline & $03 / 07 / 2020$ & $25^{\circ} 21^{\prime} 12^{\prime \prime} \mathrm{N}, 80^{\circ} 15^{\prime} 40^{\prime \prime} \mathrm{W}$ & 1 & & & & \\
\hline & $03 / 12 / 2020$ & $25^{\circ} 46^{\prime} 20^{\prime \prime} \mathrm{N}, 80^{\circ} 7^{\prime} 28^{\prime \prime} \mathrm{W}$ & 3 & & & & \\
\hline & $03 / 12 / 2020$ & $25^{\circ} 45^{\prime} 23^{\prime \prime} \mathrm{N}, 80^{\circ} 8^{\prime} 32^{\prime \prime} \mathrm{W}$ & 3 & & & & \\
\hline & 03/12/2020 & $25^{\circ} 39^{\prime} 10^{\prime \prime} \mathrm{N}, 80^{\circ} 12^{\prime} 51^{\prime \prime} \mathrm{W}$ & 4 & & & & \\
\hline & 03/17/2020 & $25^{\circ} 36^{\prime} 39^{\prime \prime} \mathrm{N}, 80^{\circ} 18^{\prime} 12^{\prime \prime} \mathrm{W}$ & 2 & & & & \\
\hline & 03/18/2020 & $25^{\circ} 43^{\prime} 22^{\prime \prime} \mathrm{N}, 80^{\circ} 13^{\prime} 13^{\prime \prime} \mathrm{W}$ & 1 & & & & \\
\hline & 03/18/2020 & $25^{\circ} 46^{\prime} 10^{\prime \prime} \mathrm{N}, 80^{\circ} 11^{\prime} 17^{\prime \prime} \mathrm{W}$ & 2 & & & & \\
\hline & $03 / 18 / 2020$ & $25^{\circ} 47^{\prime} 9^{\prime \prime} \mathrm{N}, 80^{\circ} 11^{\prime} 3^{\prime \prime} \mathrm{W}$ & 5 & & & & \\
\hline
\end{tabular}


Table 1. (continued)

\begin{tabular}{|c|c|c|c|c|c|c|c|}
\hline ID & Date & Geographic coordinates & Discrete detections (AD) & Data source & Sex & Life stage & Estimated TL (cm) \\
\hline 6 & 04/11/2018 & $25^{\circ} 39^{\prime} 57^{\prime \prime} \mathrm{N}, 80^{\circ} 15^{\prime} 30^{\prime \prime} \mathrm{W}$ & NA & IC (SRC) & $\mathrm{F}$ & Sub-adult & 340 \\
\hline 7 & $06 / 11 / 2018$ & $25^{\circ} 47^{\prime} 33^{\prime \prime} \mathrm{N}, 80^{\circ} 5^{\prime} 10^{\prime \prime} \mathrm{W}$ & NA & BRUV (SRC) & $\mathrm{F}$ & Sub-adult & 364 \\
\hline 8 & $06 / 11 / 2018$ & $25^{\circ} 47^{\prime} 34^{\prime \prime} \mathrm{N}, 80^{\circ} 5^{\prime} 10^{\prime \prime} \mathrm{W}$ & NA & IC (SRC) & ND & Adult & 430 \\
\hline 9 & $\begin{array}{l}06 / 29 / 2018 \\
03 / 20 / 2019 \\
03 / 20 / 2019\end{array}$ & $\begin{array}{l}25^{\circ} 46^{\prime} 20^{\prime \prime} \mathrm{N}, 80^{\circ} 7^{\prime} 28^{\prime \prime} \mathrm{W} \\
25^{\circ} 45^{\prime} 23^{\prime \prime} \mathrm{N}, 80^{\circ} 8^{\prime} 32^{\prime \prime} \mathrm{W} \\
25^{\circ} 45^{\prime} 43^{\prime \prime} \mathrm{N}, 80^{\circ} 8^{\prime} 58^{\prime \prime} \mathrm{W}\end{array}$ & $\begin{array}{l}3 \\
2 \\
6\end{array}$ & $\mathrm{AD}(\mathrm{FWC})$ & $\mathrm{F}$ & Sub-adult & 371.6 \\
\hline 10 & 07/03/2018 & $25^{\circ} 42^{\prime} 32^{\prime \prime} \mathrm{N}, 80^{\circ} 5^{\prime} 9^{\prime \prime} \mathrm{W}$ & NA & IC (SRC) & $\mathrm{F}$ & Sub-adult & 360 \\
\hline 11 & $\begin{array}{l}10 / 18 / 2018 \\
01 / 28 / 2019 \\
03 / 23 / 2019\end{array}$ & $\begin{array}{l}25^{\circ} 46^{\prime} 20^{\prime \prime} \mathrm{N}, 80^{\circ} 7^{\prime} 28^{\prime \prime} \mathrm{W} \\
25^{\circ} 24^{\prime} 39^{\prime \prime} \mathrm{N}, 80^{\circ} 8^{\prime} 10^{\prime \prime} \mathrm{W} \\
25^{\circ} 35^{\prime} 28^{\prime \prime} \mathrm{N}, 80^{\circ} 9^{\prime} 47^{\prime \prime} \mathrm{W}\end{array}$ & $\begin{array}{l}5 \\
6 \\
3\end{array}$ & $\mathrm{AD}$ (NOAA) & $\mathrm{F}$ & Sub-adult & 349 \\
\hline 12 & $10 / 22 / 2018$ & $25^{\circ} 46^{\prime} 20^{\prime \prime} \mathrm{N}, 80^{\circ} 7^{\prime} 28^{\prime \prime} \mathrm{W}$ & 5 & $\mathrm{AD}$ (NOAA) & $\mathrm{F}$ & Sub-adult & 364 \\
\hline 13 & $10 / 26 / 2018$ & $25^{\circ} 39^{\prime} 13^{\prime \prime} \mathrm{N}, 80^{\circ} 9^{\prime} 33^{\prime \prime} \mathrm{W}$ & NA & IC (SRC) & M & Adult & 375 \\
\hline 14 & $\begin{array}{l}10 / 30 / 2018 \\
10 / 30 / 2018 \\
03 / 12 / 2019\end{array}$ & $\begin{array}{l}25^{\circ} 46^{\prime} 20^{\prime \prime} \mathrm{N}, 80^{\circ} 7^{\prime} 28^{\prime \prime} \mathrm{W} \\
25^{\circ} 45^{\prime} 43^{\prime \prime} \mathrm{N}, 80^{\circ} 7^{\prime} 54^{\prime \prime} \mathrm{W} \\
25^{\circ} 30^{\prime} 37^{\prime \prime} \mathrm{N}, 80^{\circ} 6^{\prime} 47^{\prime \prime} \mathrm{W}\end{array}$ & $\begin{array}{l}4 \\
1 \\
1\end{array}$ & $\mathrm{AD}(\mathrm{NOAA})$ & M & Sub-adult & 293 \\
\hline
\end{tabular}

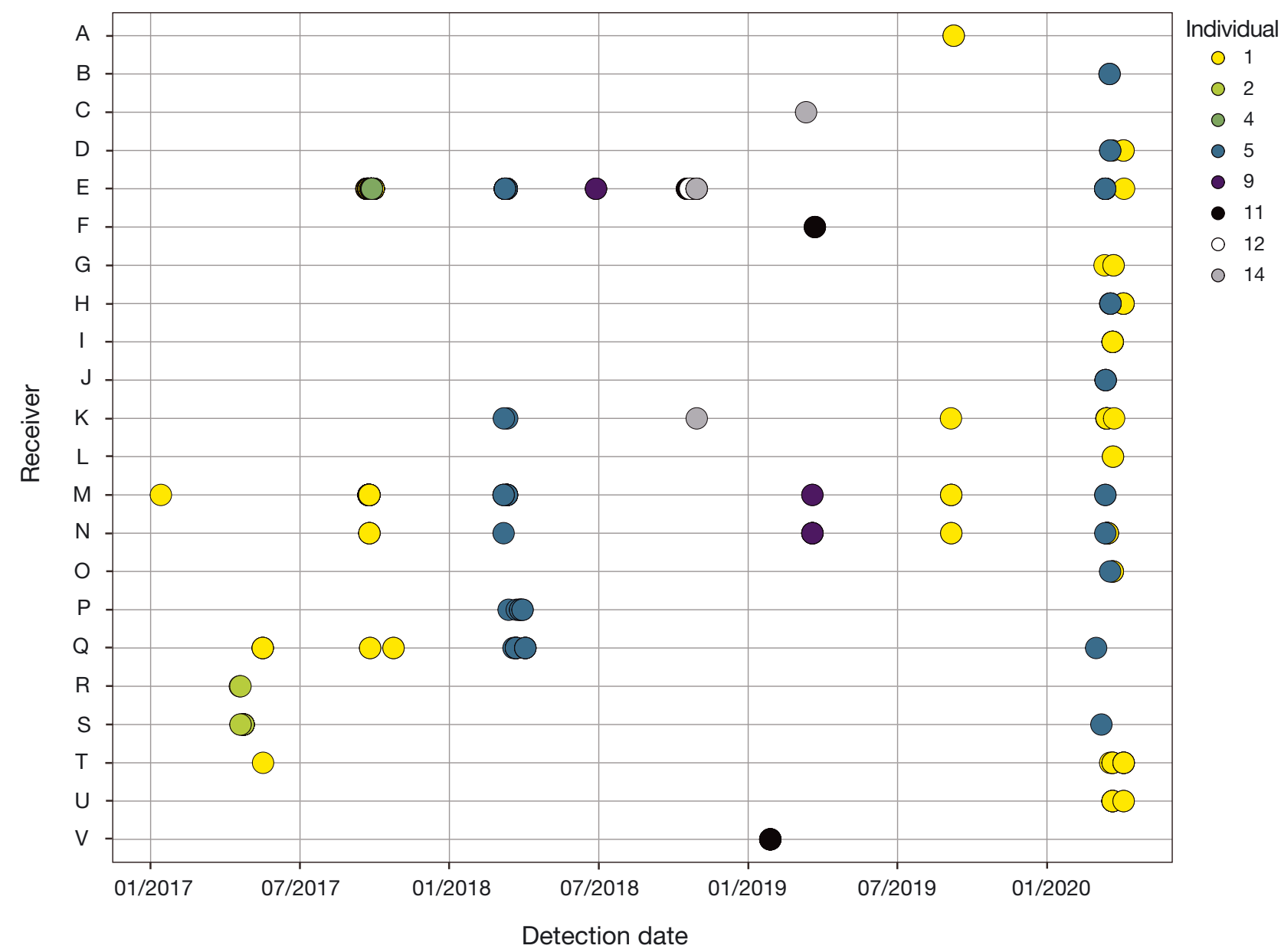

Fig. 4. Smalltooth sawfish (STS) acoustic detections in the Biscayne Bay Habitat Focus Area from January 2017 to April 2020. Detection dates are listed as month/year. Individual smalltooth sawfish $(\mathrm{N}=8)$ detected (denoted by the same ID number as in Table 1) are plotted as a different color, and each discrete detection is represented as a circle at a given receiver station (denoted by same letter as in Fig. 1) 
the city of Miami, but this was where detection opportunities by most methods, including the reporting public, were concentrated.

The exponential rate of smalltooth sawfish sightings in the Biscayne Bay HFA in the last decade is likely due in part to the increased marketing and educational efforts of the Sawfish Recovery Team to report public sightings (Brame et al. 2019). However, taken together with opportunistic encounters of 14 individuals during our research surveys in only the last $4 \mathrm{yr}$, this increase could point towards a re-emergence of smalltooth sawfish in the Biscayne Bay HFA. Some degree of regional recovery could be due to the success of the ESA listing, NOAA goals, and HFA efforts. Furthermore, recovery has likely been driven synergistically by various added state prohibitions, gillnet bans in critical habitat for juveniles, increased boater awareness, and live release by fishers arising from outreach efforts (Brame et al. 2019). The increasingly frequent encounters of adult and sub-adult smalltooth sawfish in the Biscayne Bay HFA provide a unique opportunity to further investigate these relatively understudied life stages.

Acoustic monitoring with long-lasting tags combined with other local data sources has been recognized as one of the most informative ways to monitor large- and small-scale movements of smalltooth sawfish (Poulakis \& Grubbs 2019). Results from the acoustic receivers within Biscayne Bay HFA are particularly interesting, as they demonstrate use of this area by a considerable proportion of total smalltooth sawfish individuals tagged from adjacent regions. Based on acoustic tagging data provided by J. Carlson (pers. comm.), the 6 NOAA-tagged individuals that were detected by acoustic receivers in the Biscayne Bay HFA represented almost one-third of the 21 adult and/or sub-adult smalltooth sawfish that were acoustically tagged by NOAA researchers between May 2016 and October 2019. Some tagged individuals were repeatedly detected over several days or remained within the Biscayne Bay HFA for over a month, demonstrating a certain level of site fidelity (Table 1, Fig. 4). Most acoustic detections occurred with some regularity, usually during late spring or early fall. Patterns observed from these initial data suggest that smalltooth sawfish may be migrating through the Biscayne Bay HFA along a longer corridor on an annual or semi-annual basis, stopping within the Biscayne Bay HFA for short ( days) or more prolonged ( 1-2 mo) stays. We cannot determine movement paths of the tagged sawfish from our acoustic receivers in Biscayne Bay, as they only indicate presence and absence. The seasonality observed in the detections suggests that their presence may be part of a seasonal migration, but our limited array placement does not give us directionality of movements, nor does it tell us where the individuals are ultimately going. Increased monitoring effort in this and adjoining areas would be required to enhance our understanding of the role that the Biscayne Bay HFA serves within a migration route or as a stopover point.

Interestingly, smalltooth sawfish reports and encounters were more numerous in the northern part of the Biscayne Bay HFA, which is more heavily impacted by urbanization and anthropogenic stressors, including high levels of boat traffic and recreational fishing, compared to the remaining relatively pristine, mangrove-lined coastline in the southern portion. However, both passive and active observation methods were more concentrated in the north; both acoustic recorder and BRUV efforts indicate this bias (Figs. S1 \& S2), which may prevent these data from being useful for adequately assessing smalltooth sawfish presence along the western shoreline of southern Biscayne Bay. It is still noteworthy that the majority of acoustic detections occurred at receiver sites that are subject to a high level of urbanization, such as those deployed near downtown Miami, a busy shipping channel, and popular tourist beaches (Fig. 1, receivers $\mathrm{T}, \mathrm{K}$, and $\mathrm{E}$, respectively). In addition, 8 receivers that had been deployed at least 3 yr prior (Fig. S2), 7 of which are located in urban-influenced areas in the northern part of Biscayne Bay HFA, only detected their first smalltooth sawfish during the spring of 2020. These were detections of 2 individuals that had returned to the array at several points during the previous 3 yr (Table 1: ID 1 and 5). Therefore, their most recent detections at previously unvisited receivers sites may indicate use of expanded space within the Biscayne Bay HFA by these individuals.

To date, research aimed at better understanding and mitigating the effects of biodiversity loss has focused on preserving large and pristine natural habitats, often overlooking altered urban ecosystems where less natural habitat remains (McKinney 2002). Little is currently known about smalltooth sawfish movement within urban areas. Previous research comparing estuarine nursery habitats has shown that juvenile smalltooth sawfish occupying an urbanized estuary had higher metabolic stress levels than those within a comparatively pristine estuary (Prohaska et al. 2018). Urban development leading to loss of natural coastline is thought to be a primary cause of population declines in smalltooth sawfish (Seitz \& Poulakis 2006). However, smalltooth sawfish are among many other species that continue to utilize the highly 
urbanized areas of Biscayne Bay HFA and surrounding waters, despite being subject to several synergistic stressors, including boat traffic and fishing. In addition to a more concentrated weekday and weekend boat traffic (Rider 2020), the City of Miami hosts a variety of boating shows and fishing events throughout the year. Nevertheless, the ecological shoreline of the Biscayne Bay HFA provides valuable hunting and foraging grounds for marine predators (Hammerschlag et al. 2010), and recent research has documented the use of this area by several shark species despite high levels of boat activity and vessel noise (Rider 2020). The considerable number of smalltooth sawfish detections recorded at receiver stations in urban areas is intriguing and leads to future questions about urbanization effects on habitat use by this species.

Some encounters occurred on the mainland side of south-central Biscayne Bay, downstream from an implemented component of the freshwater flow restoration efforts occurring in Biscayne Bay as part of CERP. It is plausible that the slight reduction in salinity associated with these restoration efforts has made the area more suitable for sawfish, leading to their increased occurrence there. Thus far, operations completed or in construction are located from Shoal Point $\left(25.6282^{\circ} \mathrm{N}, 80.2808^{\circ} \mathrm{W}\right)$ to Turkey Point $\left(25.4353^{\circ} \mathrm{N}\right.$, $80.3313^{\circ} \mathrm{W}$ ); however, multi-phased restoration efforts likely will span a larger length of the mainland shoreline of the bay. The extent to which these operations will affect sawfish are unknown but should be considered in future studies. Subsequent research could examine whether activities of smalltooth sawfish in the Biscayne Bay HFA could lend support to the project's ecological objectives and contribute benefits to the evaluation of planned restoration actions in the area, which could have implications for future local restoration planning.

As with any data voluntarily reported by the public, caution should be taken in interpreting ISED data. As noted earlier, increased reported encounters of smalltooth sawfish since 2000 are likely partly attributable to increased public awareness of the species, the advent of smartphones and camera technology, and the substantial efforts by ISED and NOAA to stimulate reporting via public outreach that explains the need to report sightings. However, the magnitude of increased sightings reported in recent years could also suggest a rise in the occurrence of $P$. pectinata in the Biscayne Bay HFA and be indicative of early stages of recovery, as documented in other South Florida waters (Poulakis \& Grubbs 2019). These findings are especially relevant given their previ- ously purported near-absence from the area (Lewis 2008). Citizen-based reporting systems could signal geographic expansion by sawfish or other rare species into otherwise unmonitored areas.

The present findings advocate a closer examination of the use of the Biscayne Bay HFA by smalltooth sawfish and the role this area may play in its life history, migration, and recovery. We propose the following future research priorities for this species within the Biscayne Bay HFA, with emphasis on long- and short-range movement patterns, effects of anthropogenic stressors, and population ecology:

(1) Document short-range movement patterns and habitat use of adult sawfish with augmented coverage within southwestern Biscayne Bay.

(2) Determine whether suitable nursery habitat for this species within the Biscayne Bay HFA might exist at present or with further planned freshwater inflow restoration.

(3) Determine how existing or potential smalltooth sawfish habitat will be affected by changes in freshwater distribution to Biscayne Bay expected from future restoration efforts.

(4) Evaluate the effects of coastal development and other anthropogenic activities on sawfish behavior and physiological function and their relevance to population ecology.

(5) Determine large-scale movement patterns (e.g. via satellite tracking) to address whether the Biscayne Bay HFA is a significant part of a smalltooth sawfish migratory pathway.

(6) Describe the biological and ecological characteristics of the potential resident/migratory population of smalltooth sawfish in the Biscayne Bay HFA.

Acknowledgements. We thank S. Cain, M. Rider, and A. Tinari of the University of Miami (UM) Shark Research and Conservation Program for their assistance in data compilation, as well as the UM scuba divers who assisted in acoustic receiver deployment and maintenance. We recognize the individuals who reported and provided details on their smalltooth sawfish encounters in the Biscayne Bay HFA, as well as E. Quintero and M. Riera for field assistance. The FACT network supported collaboration and data sharing for this work. We thank D. Grubbs, J. Carlson, M. Ajemian, and G. Poulakis, who were responsible for the acoustic tagging of sawfish that were detected on the Biscayne Bay receivers. Thanks to D. Grubbs and G. Poulakis, who supplied metadata for these individuals to be used in this study; D. Grubbs also provided feedback on an earlier version of this manuscript. We also thank D. Bouck for early information acquisition and NOAA Corps officers J. Europe and J. Boeck for their assistance, as well as J. Castro for his early help and guidance. Four anonymous reviewers and 3 NOAA technical reviewers provided comments that helped to strengthen earlier versions of this manuscript. Funding for acoustic receivers was provided through grants to N.H. from the 
Save Our Seas Foundation, the Ocean Tracking Network, and the Disney Conservation Fund; the NOAA Cooperative Biscayne Bay HFA supported maintenance of the acoustic receiver array. Funding for BRUVs was provided to A.J.G. from the Herbert W. Hoover Foundation and C. and M. Jones.

\section{LITERATURE CITED}

Brame AB, Wiley TR, Carlson JK, Fordham SV and others (2019) Biology, ecology, and status of the smalltooth sawfish Pristis pectinata in the USA. Endang Species Res 39: 9-23

Browder JA, Alleman R, Markley S, Ortner P, Pitts PA (2005) Biscayne Bay conceptual ecological model. Wetlands 25: 854-869

Carlson JK, Wiley T, Smith K (2013) Pristis pectinata (errata version published in 2019). The IUCN Red List of Threatened Species 2013: e.T18175 A141791261. http://dx.doi. org/10.2305/IUCN.UK.2013-1.RLTS.T18175A141791261. en (accessed 21 Jan 2019)

Carlson J, Gulak S, Simpfendorfer CA, Grubbs D, Romine J, Burgess G (2014) Movement patterns and habitat use of smalltooth sawfish, Pristis pectinata, determined using pop-up satellite archival tags. Aquat Conserv 24: 104-117

Enchelmaier AC, Babcock EA, Hammerschlag N (2020) Survey of fishes within a restored mangrove habitat of a subtropical bay. Estuar Coast Shelf Sci 244:106021

Gallagher AJ, Serafy JE, Cooke SJ, Hammerschlag N (2014) Physiological stress response, reflex impairment, and survival of five sympatric shark species following experimental capture and release. Mar Ecol Prog Ser 496: 207-218

Hammerschlag N, Morgan AB, Serafy JE (2010) Relative predation risk for fishes along a subtropical mangroveseagrass ecotone. Mar Ecol Prog Ser 401:259-267

*Hammerschlag N, Gutowsky LF, Gallagher AJ, Matich P, Cooke SJ (2017) Diel habitat use patterns of a marine apex predator (tiger shark, Galeocerdo cuvier) at a high use area exposed to dive tourism. J Exp Mar Biol Ecol 495:24-34

Lewis M (2008) Response to 'Endangered and threatened species; Initiation of a 5-year review of the endangered US Distinct Population Segment (DPS) of smalltooth sawfish'. 73 FR 29482

McKinney ML (2002) Urbanization, biodiversity, and conservation: The impacts of urbanization on native species are poorly studied, but educating a highly urbanized human population about these impacts can greatly improve species conservation in all ecosystems. Bioscience 52:883-890

NMFS (National Marine Fisheries Service) (2009) Recovery plan for smalltooth sawfish (Pristis pectinata). Prepared by the Smalltooth Sawfish Recovery Team for the National Marine Fisheries Service, Silver Spring, MD

*NOAA (National Oceanic and Atmospheric Administration) (2019) 2015-2020 Biscayne Bay Habitat Focus Area Implementation Plan. April 4. https://www.habitatblueprint. noaa.gov/wp-content/uploads/2016/04/Biscayne-BayHFA-Implementation-Plan_April-2019.pdf (accessed 10 June 2019)

Editorial responsibility: Eduardo Martins, Vancouver, British Columbia, Canada
NOAA (2020) Biscayne Bay Habitat Focus Area. June 25, 2020. https://www.fisheries.noaa.gov/southeast/habitatconservation/biscayne-bay-habitat-focus-area (accessed 28 June 2020)

*Norton SL, Wiley TR, Carlson JK, Frick AL, Poulakis GR, Simpfendorfer CA (2012) Designating critical habitat for juvenile endangered smalltooth sawfish in the United States. Mar Coast Fish 4:473-480

F Phenix LM, Tricarico D, Quintero E, Bond ME, Brandl SJ, Gallagher AJ (2019) Evaluating the effects of mobile predators on prey behavior across subtropical coastal marine habitats. Ecol Evol 9:13740-13751

* Poulakis GR, Grubbs RD (2019) Biology and ecology of sawfishes: global status of research and future outlook. Endang Species Res 39:77-90

Poulakis GR, Seitz JC (2004) Recent occurrence of the smalltooth sawfish, Pristis pectinata (Elasmobranchiomorphi: Pristidae), in Florida Bay and the Florida Keys, with comments on sawfish ecology. Fla Sci 1:27-35

Poulakis GR, Stevens PW, Timmers AA, Wiley TR, Simpfendorfer CA (2011) Abiotic affinities and spatiotemporal distribution of the endangered smalltooth sawfish, Pristis pectinata, in a south-western Florida nursery. Mar Freshw Res 62:1165-1177

*Poulakis GR, Stevens PW, Timmers AA, Stafford CJ, Simpfendorfer CA (2013) Movements of juvenile endangered smalltooth sawfish, Pristis pectinata, in an estuarine river system: use of non-main-stem river habitats and lagged responses to freshwater inflow-related changes. Environ Biol Fishes 96:763-778

Prohaska BK, Bethea DM, Poulakis GR, Scharer RM, Knotek R, Carlson JK, Grubbs RD (2018) Physiological stress in the smalltooth sawfish: effects of ontogeny, capture method, and habitat quality. Endang Species Res 36: 121-135

Rider MJ (2020) Habitat use patterns of coastal shark species in relation to boat activity along an urban marine gradient. MSc thesis, University of Miami, Miami, FL

* Scharer RM, Stevens PW, Shea CP, Poulakis GR (2017) All nurseries are not created equal: large-scale habitat use patterns in two smalltooth sawfish nurseries. Endang Species Res 34:473-492

* Seitz JC, Poulakis GR (2006) Anthropogenic effects on the smalltooth sawfish (Pristis pectinata) in the United States. Mar Pollut Bull 52:1533-1540

* Simpfendorfer CA, Yelser BG, Wiley TR, Poulakis GR, Stevens PW, Heupel MR (2011) Environmental influences on the spatial ecology of juvenile smalltooth sawfish (Pristis pectinata): results from acoustic monitoring. PLOS ONE 6:e16918

Todd PA, Heery EC, Loke LH, Thurstan RH, Kotze DJ, Swan C (2019) Towards an urban marine ecology: characterizing the drivers, patterns and processes of marine ecosystems in coastal cities. Oikos 128:1215-1242

USACE (United States Army Corps of Engineers) (2019) Comprehensive Everglades restoration plan - Biscayne Bay coastal wetlands. Fact Sheet. March 2019. https:// www.saj.usace.army.mil/About/Congressional-FactSheets-2019/CERP-Biscayne-Bay-Coastal-Wetlands-C/ (accessed 10 Oct 2019)

Submitted: February 10, 2020; Accepted: October 15, 2020 Proofs received from author(s): December 15, 2020 